\title{
The post-Holocaust memoir:
}

\section{0 years after 50 years later}

Anne Karpf ${ }^{1}$

The War After (Karpf, 1996), a family memoir about the psycho-social effects of the Holocaust on the children of survivors, attracted considerable attention when first published. 20 years later, Karpf argues, it can be read as an example of post-postmemory. Hirsch (2012) defined postmemory as those memories of the Holocaust that the 'second generation' had of events that shaped their lives but took place before they were born. Post-postmemory, Karpf suggests, is the process whereby such narratives are themselves modified by subsequent events and re-readings brought about by three kinds of time - personal, historical and discursive. Although inevitable, such re-readings run the risk of encouraging Holocaust revisionism and denial. Nevertheless, Karpf claims, they are essential to maintain the post-memoir as a living text.

This paper explores the life and afterlife of memoir through the lens of one particular example of the genre. It addresses principally the question of time and vantage-point in the memoir. Since understanding can evolve and perspectives modify over time, can the memoir's insights ever be anything other than contingent? If we understand memory as historically produced, does this necessarily reduce the memoir's truth claims, its status as testimony? And how can we allow for the fluidity and dynamism of interpretation without acceding to relativism? These questions become all the more charged in the case of the post-Holocaust memoir.

This term itself needs defining and qualifying. In some sense it is tautological: virtually all Holocaust memoirs, save those few examples written at the time by members of the Sonder Kommando itself and buried in the grounds of Birkenau (which have come to be known as the Scrolls of Auschwitz $)^{2}$, are effectively post-Holocaust, in the sense that they were written after the end of the second world war and certainly published only after it, sometimes considerably later. What is

\footnotetext{
${ }^{1}$ London Metropolitan University, United Kingdom.

${ }^{2}$ These have been brilliantly analysed by Chare and Williams, viz. Nicholas CHARE and Dominic WILLIAMS, eds., Representing Auschwitz: At the Margins of Testimony, Basingstoke, Hants, Palgrave Macmillan, 2013 and Nicholas CHARE and Dominic WILLIAMS, Matters of Testimony: Interpreting the Scrolls of Auschwitz, Oxford: Berghahn Books, 2016.
} 
intended in this shorthand term, however, is here something more specific: the genus of memoir written by children of Holocaust survivors. Its usage here is a nod to the term applied to such memoirs by Marianne Hirsch, who sees them as an example of 'postmemory'

\section{Postmemory}

The genre, inaugurated by Helen Epstein's book, Children of the Holocaust ${ }^{3}$ in 1979, has mushroomed in the intervening decades: while Epstein's account was rooted in the American experience, later contributions homed in on the experiences of children of Holocaust survivors in Australia, Israel, France and the UK. These discussed the psycho-social impact on them of their parents' wartime experiences, not only in relation to the countries that they came from or in which their war years were spent, but especially with reference to those countries where they settled after the war and where their children, the authors of these memoirs, were raised.

This paper focuses on one such account, my own memoir, The War After: Living With the Holocaust (hereafter TWA), first published in 1996 in the UK and as Der Krieg Danach in Germany in 1998, and republished in the UK in $2008^{4}$. It consists of three parts. Part 1 intercuts a narrative of my own experiences, growing up in the UK as the daughter of Holocaust survivors (my mother, Natalia, who survived the Nazi concentration and extermination camps Plaszow, Auschwitz and Lichtewerden; and my father, Josef, a survivor of Russian labour camps) with edited transcripts of my interviews with my parents about their lives before, during and after the war. Part 2, comprising three chapters, explores through historical accounts British reaction to Jewish refugees from mainland Europe arriving in Britain before the war and to survivors of the Holocaust who arrived after the war. It also critically scrutinises the psychological literature on the impact of the Holocaust on both survivors and their families. Part 3 returns to my own personal story and describes my attempt, through the processes of psychoanalysis, having children and writing the memoir, to attain some kind of accommodation with both my parents' and my own experiences.

The book, when it was first published, attracted much critical attention and became a kind of samizdat, passed between survivors families. (I received over 100 letters from children of refugees and survivors who felt that their lives had been similarly affected.) Over the years it has also been the subject of considerable academic discussion - reviewed, according to Lassner, « as a

\footnotetext{
${ }^{3}$ Helen EPSTEIN, Children of the Holocaust: Conversations with Sons and Daughters of Survivors, New York, Putnam, 1979

${ }^{4}$ Anne KARPF, The War After: Living With the Holocaust. London, Heinemann, 1996.
} 
significant contribution to literature of the Second Generation $»^{5}$, while Jilovsky saw it as instrumental in bringing the experience of the 'second generation' to the attention of the wider population in the UK ${ }^{6}$. Eaglestone judged it « very revealing and quite courageous $»^{7}$, while PellicerOrtín analysed it as a 'liminal work' and an example of a 'limit-case autobiography'8.

Hirsch saw it as an example of 'postmemory'. She defines this as

\begin{abstract}
the relationship that the 'generation after' bears to the personal, collective, and cultural trauma of those who came before - to experiences they 'remember' only by means of the stories, images and behaviours among which they grew up. But these experiences were transmitted to them so deeply and affectively as to seem to constitute memories in their own right. Postmemory's connection to the past is actually mediated not by recall but by imaginative investment, projection, and creation... These events happened in the past, but their effects continue into the present ${ }^{9}$.
\end{abstract}

This is not the place to discuss the value, limitations or subsequent critiques of the concept, nor its occasional misrepresentation ${ }^{10}$. What is relevant for our purposes is that implicit in 'postmemory' are two kinds of time: the experience of the parents, and that of their children.

\footnotetext{
${ }^{5}$ Phyllis LASSNER, The Transgenerational Haunting of Anne Karpf and Lisa Appignanesi, in Phyllis $\quad$ LASSNER, Anglo-Jewish Women Writing the Holocaust Basingstoke, Hants, Palgrave Macmillan, 2008, p.116.

${ }^{6}$ Esther JILOVSKY, Recreating Postmemory? Children of Holocaust Survivors and the Journey to Auschwitz, colloquy 15,2008 , pp. 145-162.

${ }^{7}$ Robert EAGLESTONE, The Holocaust and the Postmodern, Oxford, Oxford University Press, 2004, p. 86.

${ }^{8}$ Silvia PELLICER-ORTIN, « Separateness and Connectedness: Generational Trauma and the Ethical Impulse in Anne Karpf's 'The War After: Living With the Holocaust », in Susana ONEGA and Jean-Michel GANTEAU, Contemporary Trauma Narratives: Liminality and the Ethics of Form, New York, Routledge, 2014, pp. 193-210. ${ }^{9}$ Marianne HIRSCH, The Generation of Postmemory: Writing and Visual Culture After the Holocaust, New York, Columbia University Press, 2012, p.5

${ }^{10}$ Franklin, for example, misrepresents The War After as demonstrating « Holocaust obsession literally enacted by the body » (Ruth FRANKLIN, A Thousand Darknesses: Lies and Truth in Holocaust Fiction, New York, OUP USA, 2011, p. 223) when the book explicitly repudiates such a reading.
} 


\section{Post-postmemory}

I want to propose a third time ${ }^{11}$ : that of 'post-postmemory'. This somewhat ungainly term signals the afterlife of memoir - the changing ways in which both authors and readers understand and re-intepret an autobiography years after it was originally published. My first inkling that this might need problematising came as TWA was being prepared for republication and I began to think about transformations that had taken place in the 14 years since its first appearance. It seemed to me that these might be roughly summarised as the effects of changes in personal time, chronological time and discursive time.

While I did not renounce the explanatory model proffered by TWA, I felt that it needed qualifying (in ways which, alas, were not possible, as this was now a POD - publication on demand - volume, scanned from the original, with only the merest alterations permissible). The desire to revise autobiography is not unusual: Edward Gibbon published six different versions of his $\mathrm{Me}$ moirs of My Life between 1788 and $1793^{12}$. This impulse results not only from authorial change of mind but also from external factors. The publication of Freud's Moses and Monotheism was staggered between 1934 and 1938: publication of the third part was withheld until 1938, after Freud had left Vienna, because he feared that its publication might lead to the banning of psychoanalysis ${ }^{13}$. Caruth argues that, because of the 'latency' of traumatic experience, the period during which its effects are not apparent, an 'incubation period' is in any case needed before traumatic experiences can be assimilated and made referential ${ }^{14}$. Nabokov 'assiduously revised' his 1951 memoir in 1966, arguing that a lack of data in regard to family history had hobbled his earlier version; in the subsequent one 'consistent chronological blunders' were corrected ${ }^{15}$. Even more relevant to this discussion is Eli Wiesel's controversial rewriting of his Holocaust memoir, Night (originally categorised as a novel). First published in Yiddish in 1956, Wiesel claimed that he had

\footnotetext{
${ }^{11}$ In fact, in TWA, there already is a third time: the 13 years between the recording of the earliest interviews with my parents and their publication in transcribed, edited form.

${ }^{12}$ Edward GIBBON, Memoirs of My Life, London, Penguin Classics, 1984 [1788].

${ }^{13}$ Cathy CARUTH, Unclaimed Experience: Trauma and the Possibility of History, Yale French Studies, no.39: Literature and the Ethical Question, 1991, pp.181-192.

${ }^{14} \mathrm{Ibid}$., although the Scrolls of Auschwitz would seem to challenge this formulation - see : Nicholas CHARE and Dominic WILLIAMS, eds., Representing Auschwitz: At the Margins of Testimony, Basingstoke, Hants, Palgrave Macmillan, 2013 ; N. CHARE and D. WILLIAMS, Matters of Testimony: Interpreting the Scrolls of Auschwitz, Oxford: Berghahn Books, 2016.

${ }^{15}$ Vladimir NABOKOV, Speak Memory: An Autobiography Revisited, London, Penguin Books, 2000, p. xii.
} 
been able, in the 2006 English translation by his wife Marion Wiesel, to « correct and revise a number of important details $»^{16}$. Others have maintained that he simply made things up, telling later readers what they wanted to hear ${ }^{17}$.

So common has this repeated self-presentation become that it has acquired its own moniker, the 'serial memoir'. According to Stamant, this developed in the second half of the 20th century in tandem with postmodern thought and changes in technology. «It is a postmodern form of selfrepresentation: relational, experimental, historical and permanently shifting.... Serial memoir is a textual, material manifestation of a larger serial culture, marking a crucial shift in how people understand themselves and narrate their life stories $»^{18}$.

Personal time is always, of course, connected with historical time. As Halbwachs remarked, «It is in society that people normally acquire their memories. It is also in society that they recall, recognize and localise their memories... the past is not preserved but is reconstructed on the basis of the present $»^{19}$. Halbwachs placed individual memory always in collective memory and social frameworks - an approach that his translator called 'presentist' ${ }^{20}$. In my own case, the 'remembering self' changed and so, naturally, did the 'remembered self'. As the result of further psychoanalysis my understanding of some of the events, attitudes and experiences described in TWA shifted: in the decades since its publication I have been able to draw on a broader interpretive repertoire. I had tried not to fossilise my explanations in $T W A$, attempting rather, as Lassner ${ }^{21}$ notes, to juxtapose my experiences and those of my parents rather than assuming a causal link. (Indeed I attempted to problematise the very notion of any easy causality between them, suggesting, rather, that the connections between them were necessarily complex.) Of course as those relationships changed over time so too did my perception of them, so that in many instances my parents' Holocaust experiences no longer seemed the sole, or most significant, influence on certain aspects of our relationship.

\footnotetext{
${ }^{16}$ Eli WIESEL, Night, transl. by Marion WIESEL, New York: Hill and Wang, 2006, p.xii.

${ }^{17}$ See, for example, Alexander COCKBURN, Truth and Fiction in Elie Wiesel's 'Night', Counterpunch, Jan 07 2016. Accessed 2.5.2017, http://www.counterpunch.org/2016/07/01/truth-and-fiction-in-elie-wiesels-night-2/.

${ }^{18}$ Nicole STAMANT, Serial Memoir: Archiving American Lives, Basingstoke, Hants, Palgrave Macmillan, 2014, pp. 2-4.

${ }^{19}$ Maurice HALBWACHS, On Collective Memory, transl. Lewis A. COSER, Chicago, University of Chicago Press, 1992, pp. 38-40.

${ }^{20}$ Ibid., p. 25.

${ }^{21}$ Phyllis LASSNER, The Transgenerational Haunting of Anne Karpf and Lisa Appignanesi, in Phyllis LASSNER, Anglo-Jewish Women Writing the Holocaust Basingstoke, Hants, Palgrave Macmillan, 2008.
} 
Through having children my concerns also altered : I began to view life more as a mother than as a daughter, and to identify with my mother in the maternal role. I now looked forward more than backwards, and worried about my influence on my daughters rather than that of my parents on me. These are the perhaps inevitable shifts that occur across the life course to those who have children but they have enormous bearing on the account one cleaves to of one's own childhood, which must necessarily also change over the life course.

Primo Levi described the 'crystallization' of memory in stories that restructure meaning so that the experience that underpins them then, as a result, gets lost to memory ${ }^{22}$ : in Judith Butler's words, «the story threatens to substitute for the events it relays $»^{23}$. In TWA I suggest that this is precisely what happened to me with my parents' stories of their wartime experiences: they acquired a 'storyness' that allowed me to detach myself from the trauma that underlay them. The concept of 'post-postmemory' challenges such a crystallization: it enables the account in TWA to itself undergo revision, to decrystalize the stories it tells.

Of course autobiography always contains within itself its own justification: the narrative is shaped in the form of a defence or special pleading, and what we need to defend, or defend ourselves against, will change. In my case, the very fact of writing and speaking publicly about my experience as the daughter of Holocaust survivors growing up in Britain changed those experiences: narrative transforms understanding which works upon meaning to produce fresh narratives. Narrative is not just about a life but is itself alive. In Butler's words, « Language not only records, preserves and transmits... Language also invariably works upon the material it records, preserves, transmits $»^{24}$. The writing of TWA was an attempt - to some extent a successful one to destigmatise some of the abject feelings that had accompanied me through childhood. It risked, however, freezing me in another narrative in which being the child of Holocaust survivors constituted the entirety of my experience and not just a part of it - another crystallization.

Chronological time has also worked upon the past: as the remaining Holocaust survivors age and die, they become unable to re-author their own story, remaining instead fixed in the role that they occupied as recently-liberated survivor parents of young children. Compared to this, the relationships between old survivor parents and their adult children may be very different indeed.

\footnotetext{
${ }^{22}$ Primo LEVI, The Drowned and the Saved, transl. Raymond ROSENTHAL, New York, Random House, 1989. ${ }^{23}$ Judith BUTLER, Primo Levi for the Present, in Frank ANKERSMIT et al., eds., Re-figuring Hayden White, Stanford, Stanford University Press, p. 292.
}

${ }^{24}$ Ibid., p. 295. 


\section{Discursive shifts}

The third, and perhaps most significant, transformation that has taken place since the original publication of TWA in 1996 is discursive. Following Halbwachs, Crown argues that we need to historicise the act of recall ${ }^{25}$. I remembered in 1996 in the context of an enormous cultural forgetting of the Holocaust - an amnesia, ignorance and silence that had only just begun to be breached. In 2016 I remember in the context of over-memorialisation. The Holocaust has become widely available as a cultural trope and political tool. To take just one specific example: in 1996 I readily employed the term 'second generation' to refer to the children of Holocaust survivors. Today I feel uncomfortable with such a designation - not because I have been persuaded by critics of the concept of postmemory but in the light of the use and abuse of the Holocaust by those who wish to borrow the cultural capital that Holocaust suffering has come horribly to endow, a kind of hanging on to their coat-tails. The connotations of the term seem to me to have changed: its use today runs the risk of diluting the experience of survivors and creating out of the suffering that they underwent something aspirational.

Discursive changes shape not only what can be thought about and spoken; they also affects its meaning. What, in 1996, might have stood both as a claim for public attention and as act of recording and memorial reads differently in an era rife with memoir and where those by both survivors and their children have begun to merge into a composite, a palimpsest of history, a kind of collective memoir in which individual stories lose their particularity and are unmoored from the historical moment in which they were created. Before I started writing TWA the Holocaust narrative in my family - and for most of my childhood - felt private and almost hidden. Today such stories are regularly aired and play a prominent part in public discourse. Through the publication of TWA and the public speaking and writing that I did around it, I played a small part in contributing to this discursive change in the UK - a discursive change that has also meant that $T W A$ is today read differently: seen by some as part of a genre that did not really exist when I began to write it.

\section{The unstable 'I’}

To return, for a moment, to personal time, the kind of revisiting of experience described here is a common aspect of ageing: the vantage-point shifts. In the case of published texts, their revision

\footnotetext{
${ }^{25}$ Richard CROWNSHAW, The Afterlife of Holocaust Memory in Contemporary Literature and Culture, Basingstoke, Hants, Palgrave Macmillan, 2010.
} 
challenges the notion of a stable subjectivity or unified identity which has long shaped the common narrative trajectory of the biography or autobiography, with its passage from challenges overcome to resolution and the assertion of a new, improved identity. ${ }^{26}$ Postmodern texts eschew such a conception of the self. Smith and Watson, for example, identify four different 'I's in the memoir: the 'real' or historical 'I', the narrating 'I', the narrated 'I' and the ideological ' $I$ '27. Stamant goes further.

Memoir allows for a multiplicity of subject positions which pose a challenge to the possibility of having, much less knowing, an 'interior self'; the construct of the 'I' exposes the idea of a cohesive, consistent 'interior self' as fictive... Serial memoir confronts traditional concepts of unified identity and history, presenting a discursive mode that embraces multiplicity, relationality, and historicity... which dismantle[s] grand autobiographical and historical narratives ${ }^{28}$

To this end Stamant champions techniques such as fragmentation, reflexivity, narrative discontinuities and simultaneity used by writers to challenge traditional generic boundaries and categories. Some of these techniques were deployed inTWA : indeed Pellicer-Ortín draws attention to the polyphonic voices and variety of discourses evident in « this liminal work, a collage made up of the fragmentary pieces of her individual, familial and collective past... the combination of genres representing the impossibility of representing trauma in a simple way and the difficulties in constructing a continuous narrative out of Karpf's fragmentary memories $»^{29}$.

Digital technologies facilitate and even encourage fragmentation and revision: I could, if I wanted to (I do not), through the medium of a blog constantly revisit and re-interpret TWA so that it becomes a self-renewing memoir - the war ever after. But there is a problem with such an approach when applied to postmemory: its impact on that part of my narrative made up of my parents' stories. It is one thing for survivors to revisit their own testimony. At least since Young explored the principles of narrativity embedded in Holocaust testimony ${ }^{30}$, the ways in which

\footnotetext{
${ }^{26}$ It has sometimes seemed as if the only way of challenging this has been to reverse it, e.g. Alexander MASTERS, Stuart: A Life Backwards, London, Harper Collins, 2006.

${ }^{27}$ Sidonie SMITH and Julia WATSON, Reading Autobiography: A Guide for Interpreting Life Narratives, Minneapolis, University of Minnesota, 2001.

${ }^{28}$ N. STAMANT, Serial Memoir: Archiving American Lives, op. cit., p. 5

${ }^{29}$ S. PELLICER-ORTIN, « Separateness and Connectedness: etc. », op cit, pp.197-199.

${ }^{30}$ James YOUNG, Writing and Rewriting the Holocaust: Narrative and the Consequences of Interpretation, Bloomington, IND, Indiana University Press, 1990s.
} 
survivors' accounts are constructed as a form of historical exegesis is commonly acknowledged. There are also examples of survivors refashioning their own accounts (eg Wiesel) or even reconstituting them through a different discourse - most remarkably in the case of Otto Lev Kulka ${ }^{31}$, the Czech historian and survivor of Auschwitz, who used an affectless third person to describe his experiences in the camp until, in his most recent remarkable book, he recovers the experience in a voice saturated with subjectivity and affect, and laced with dreams and speculation.

Jilovsky claims that postmemory memoirs are « a type of indirect Holocaust testimony... Such memoirs are instances of secondary witnessing, because they re-tell the Holocaust story of family members connected to the author $»^{32}$. As such they confer a special responsibility upon their authors. If we accept that the memoir necessarily offers a historicised, contingent point of view, what impact might this have on their use of primary testimony - that of their survivor parents? Might it 'contaminate' them ? I have argued elsewhere that Holocaust researchers and writers should examine their own emotional engagement with the trauma that they are studying and in which they inevitably become psychologically enfolded, and that neither a positivist approach nor a sacralising of testimony serve us well ${ }^{33}$. At the same time, as Stone has pointed out, Holocaust history is "methodologically quite staid" ${ }^{34}$. It would be unfortunate indeed if post-postmemory or a postpositivist challenge to the grand narrative were to open the door to Holocaust denial.

\section{Holocaust revisionism}

There is another risk in post-postmemory. The Holocaust has increasingly been appropriated as a weapon in current political disputes, so that memory is deployed to serve present ideological needs, for example in the Middle East, and in heated recent British discussion of anti-semitism. ${ }^{35}$

\footnotetext{
${ }^{31}$ Otto Lev KULKA, Landscapes of the Metropolis of Death: Reflections of Memory and Imagination, Transl. by Ralph MANDEL, London, Allen Lane, 2013.

${ }^{32}$ E. JILOVSKY, Recreating Postmemory? Children of Holocaust Survivors and the Journey to Auschwitz, op. cit., p. 146.

${ }^{33}$ A. KARPF, Chain of Testimony: The Holocaust Researcher as Surrogate Witness, in N. CHARE and D. WILLIAMS, eds., Representing Auschwitz: At the Margins of Testimony, op. cit.

${ }^{34}$ Dan STONE, «Introduction », in id. The Holocaust and Historical Methodology, Oxford, Berghahn Books, 2012.

${ }^{35}$ See, for example, Peter NOVICK, The Holocaust and Collective Memory, London, Bloomsbury, 1999; Idith ZERTAL, Israel's Holocaust and the Politics of Nationhood, Cambridge, Cambridge University Press, 2008; A.
} 
By embracing re-readings of memoir, we open the door to such abuses of memory, to the Holocaust being used as a means of both silencing debate and shaping it. This is unavoidable, and can only be combated by the scrupulous use of history. As Butler notes, "We cannot fully control the discursive uses of the story $»^{36}$.

Butler has discussed ways of preserving the 'referentiality' of the events of the Holocaust. These, however, need not, ought not depend on their immutability. Changes in narrative do not necessarily usurp or displace previous versions or render them suspect: they add to them so that memory becomes richer - multi-faceted and three-dimensional. Memoir can never become a simulacrum of experience or arrive at some definitive version of the past: it is inevitably contested and reframed. By becoming more fluid and less sclerotic, its sinews and arteries become fuller and more elastic - more pumped with blood. This is so even in the case of Holocaust testimony for, if we situate the Holocaust as in some sense outside or beyond memory, we not only, paradoxically, risk inadvertently feeding Holocaust denial when divergences or re-interpretations arise (as they surely will and must), but we also risk dehumanising it, as though it were so monumental an atrocity as to somehow stand outside time and human agency altogether. Calcifying Holocaust testimony and postmemory will not enable them to withstand Holocaust revisionism better; on the contrary, such an approach renders them more vulnerable to its calumnies. Better by far not to embark on this path and acknowledge instead that time necessarily shapes, and re-shapes, all Holocaust testimony, all postmemory.

In the words of Walter Benjamin, « To articulate the past does not mean to recognise 'how it really was'. It means to take control of memory as it flashes in a moment of danger ${ }^{37}$.

KARPF, The 'Arab Nazi' and the 'Nazi Jew', in A. KARPF et al, eds., A Time to Speak Out: Independent Jewish Voices of Israel, Zionism and Jewish Identity, London, Verso, 2008.

${ }^{36}$ Judith BUTLER, «Primo Levi for the Present », in F. ANKERSMIT et al., eds., Re-figuring Hayden White, op cit., p. 296.

${ }^{37}$ Walter BENJAMIN, http://www.sfu.ca/ andrewf/CONCEPT2.html. Accessed 17.6.16 



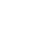


